\title{
THE SPECIFICS OF HOSHIN KANRI AS A METHODOLOGY FOR SUCCESSFUL STRATEGIC MANAGEMENT OF ORGANIZATIONS
}

\author{
Radka P. Ivanova \\ Assoc. Prof. Dr., University of Economics Varna, Bulgaria, r.ivanova@ue-varna.bg
}

\begin{abstract}
Hoshin Kanri is a management methodology that allows concentrating the energy and capabilities of all the employees to develop up-to-date goals and flexible action plans, to develop creativity and active communication, to discover new sources of funds and ideas, by targeting utilization of all available resources. At the heart of the Hoshin Kanri is the idea of continuously improving the quality characteristics of the organization, taking into account changes in the external environment, what has been achieved so far and forecasts for future development. A guiding principle is the participation of all those working in the organization, "grasping" ideas, discussing them jointly, consensual selection and identifying appropriate ways to implement them. The purpose of this article is to bring out the specifics of Hoshin Kanri for managing organizations in strategic terms.
\end{abstract}

Keywords: Hoshin Kanri, TQM, PDCA, Catchball, Ringi.

\section{INTRODUCTION}

An important prerequisite for the successful activity of each organization is the development of flexible plans that allow it to adapt to the changing environment conditions. The long-term and medium-term plans represent the two components of the Japanese management concept, which has gained popularity under the name Hoshin Kanri. It requires the removal of critical questions and imperatives for the organization's activities, the definition of long-term and key objectives, their hierarchical ranking according to the degree of importance, the de-establishment of the criteria for evaluating the results obtained and the provision of daily measures for a successful business. Hoshin Kanri is interpreted as a strategic planning process, in the course of which full coordination of the actions and views of the organization's staff for the implementation of the identified methods of improvement must be achieved. It requires a rationally developed strategy based on continuous feedback, allowing monitoring and evaluation of each activity in the organization.

Hoshin Kanri is associated with the need to track actions, measure achievements, analyze the experience gained, correctly interpret the collected data, and combine the efforts of everyone working in the organization in formulating its goals and implementing the plans. At its base, Hoshin Kanri is associated with building a comprehensive quality management, initially focused only on its control, and eventually acquiring a wider scope.

\section{HOSHIN KANRI}

\subsection{Occurrence and Characteristics of Hoshin Kanri}

The concept of Hoshin Kanri began in the 1950s, initially associated with the names of researchers Edward Deming and Joseph Juran and their work in Japan to restore its economy after World War II. However, the management methodology only gained popularity in the 1960s, thanks to its application in large companies such as Bridgestone, Toyota, Komatsu, Danaher and others. The main purpose of Hoshin Kanri is to strengthen the operational strategy of the organization and constantly improve the quality (Paraschivescu, 
2018, p.91). Researchers in the field are united around the thesis that there is no unambiguous English translation of the Japanese phrase Hoshin Kanri. In general, we can point out that it is used to describe a systematic approach that makes it possible to achieve the necessary consistency between the organizational strategy and the activities undertaken (implementation). From an etymological point of view, "Hoshin" means course, policy, plan, goal, and "Kanri" - administration, management, planning, control, care (Hutchins, 2015, p.3; Paraschivescu, 2018, p.92; Souad, Messaouda, Maazouzi,2017, p.3). In the concept of hoshin there are two components: ho - direction and shin - focus, shiny metal. Their combination stands for "shiny metal" or "shiny needle pointing the direction (i.e. compass)". Kanri also consists of two components: kan alignment and ri -cause. As a result, Hoshin Kanri is seen as a process defining the strategic direction of development of the organization (Winiarski, 2006). Hoshin Kanri therefore comes down to transforming the strategic and quality objectives of companies formulated by senior managers to quantitative targets and concrete actions from each of the lower management levels. Paraschivescu $(2018$, p. 92) also points out that Hoshin Kanri is defined as a strategic planning process aimed at ensuring that the mission, vision and objectives are known to everyone in the organization and implemented by all its staff.

Researchers in the field agree that the greater popularity the method Hoshin Kanri received only after the first English translation of Yoji Akao's book "Hoshin Kanri: Policy Deployment for Successful TQM" (1991) was published. Therefore, this book is defined as the "bible" of the Hoshin Kanri concept. In it, Y. Akao defines Hoshin Kanri as a set of activities within the organization that allow systematic achievement of the objectives set and ensuring the gradual planning, implementation and verification of the processes for improving the companies. This, in turn, is closely linked to continuous improvement of the quality of processes, products, services, which in practice underpins the Concept of Total Quality Management (TQM). One of the key features of TQM is the understanding that each person is a specialist in their field, strives for recognition and validation of their workplace, and has self-awareness and continuous self-control over their activities to provide their own contribution to quality improvement (Hutchins, 2015).

Hoshin Kanri's main idea is the understanding that the quality of the product is a consequence of the qualities of the organization, and Hoshin Kanri is a means of designing the qualities of the organization. Also, Hoshin Kanri can also be interpreted as a policy that forms sustainable competitive advantages for companies. As Ćwiklicki and Obora (2011, p. 217) point out, Hoshin Kanri is a system for improving overall capacity by focusing on improving the organization's performance, strategic governance, and the need to use appropriate quality control methods. The comparison between Hosin Kanri and TQM shows that Hoshin Kanri defines what the organization wants to achieve and TQM is the means by which a match can be achieved between the current and targeted performance of the organization (Hutchins, 2015, p.3).

Winarski (2006) develops the thesis that Hoshin Kanri started by formulating the strategic plans of companies, identifying priority areas for improvement, indicators, goals and action plans to help realize strategic intentions. It is important for Hoshin Kanri's success to properly rank the strategic objectives set out, as well as the elaboration on each one of them, in order to accurately select adequate evaluation indicators and plans with concrete actions to achieve them. The plans developed should express the feeling that the organization will be able to achieve its goal once it has traveled the targeted path.

The following are displayed as the main elements of Hoshin Kanri in specialized literature:

- Vision and mission;

- $\quad$ Setting goals;

- Policy development and implementation;

- Continuous communication;

- Control of actions and results;

- Feedback;

- Adaptation;

- Continuous improvement

Success implies setting achievable targets, defining appropriate actions and evaluation criteria, and continuous control over them. The implementation of total quality control from a Japanese point of view implies the use of all possible methods and techniques, including Six Sigma, Lean Manufacturing, Total Productive Maintenance, Quality Function Deployment, Quality Circles, etc. Their focus is on quality and continuous improvement. In practice, Hoshin Kanri should be seen as a means of managing changes in 
organizations through coordinated processes. At its core is the Edward Deming Cycle - PDCA (Plan-DoCheck-Act), which researchers see as a Hoshin Kanri methodology (Ahmed, 2016, p.159; Alic \& Ideskog, 2016, p.6; Butterworth, 2001, p.80; Cwiklicki, 2010, p.817; Häggström, 2004, p.16; Nicholas, 2014; Paraschivescu, 2018, p.94; Souad, Messaouda and Maazouzi, 2017, p.4; Tennant, C., Roberts, Tennant \& Roberts, 2001; Witcher, 2014; Zairi and Erskine, p. 2; Witcher, 2003, p.85, etc.). The first component, Planning (Plan) is associated with the formulation of objectives, the definition of the roles and responsibilities of the staff, the development of a timetable for the implementation of the identified activities. The second component - Implementation (Do) - is limited to implementing the actions provided for in the plan, as well as collecting data for subsequent compilation of diagrams and analyses. The third component - Check requires the use of systematic and methodical means to measure the degree of progress in the organization. This implies analyzing the information collected, which can assess the level of implementation of the planned events and identify possible discrepancies between expected and actual results. The comparison of data from several consecutive PDCA cycles makes it easier to detect trends in the development of organization. The fourth component, Act or correction, consists in identifying the reasons for the variances identified, discussing them and taking adequate corrective action. The PDCA cycle is repeated continuously, with the main prerequisite for success being for everyone working in the organization to participate, regardless of their place in its hierarchy.

The implementation of Hoshin Kanri implies that, when formulating the objectives, account shall be taken of the views at different levels of the management hierarchy in order for the vision of senior management to be transformed into a set of coherent, consistent, clear, comprehensible, achievable actions and policies respectively. The following are stated as the main prerequisites for the implementation of Hoshin Kanri in the organizations: thorough analysis of the system; defining the main objectives of the business; establishing the environment in which organizations to function, including the ecological environment (Souad, Messaouda and Maazouzi, 2017, p.4). Hoshin Kanri achieves improvement of ongoing activity (in terms of quality, efficiency, processes), more complete and timely problem solving in the organization, expanding opportunities for innovation, continuous training and creating conditions for personal and/or team development.

An important feature of the Hoshin Kanri method is the ability of all those working in the organization to contribute to the formulation of the goals and, subsequently, to determine the specific actions to achieve them. As a result, each employee contributes through appropriate thinking, giving ideas and work on their implementation to improve the organization. The joint development of action objectives and policies makes them more successful than those dropped from above (by the senior manager). In practice, the main distinction between Hoshin Kanri as a management method comes down to the timely "grasp", sharing and universal approval of the company's goals. This allows for easier and more effective implementation of a plan and policies, as all the staff have engaged with them already in the process of developing them.

The following are set out as the basic principles of Hoshin Kanri:

- Setting a limited number of targets to be achieved within one year;

- Determining the precise steps to achieve the objectives and constantly reviewing them;

- Gathering information about each level of the organization;

- Everyone working in the organization responsibly performs their tasks;

- Use the "catch the ball" game to ensure that each idea has passed for top-to-bottom discussion and vice versa.

A map describing the characteristics of Hoshin Kanri is used to visualize the goals set for the relevant year. It shall include general information about the organization: name, ownership, units/departments. The targets shall be broken down by month within the calendar year in order to make it clear to everyone what they need to focus on and their efforts during the relevant period. The level of implementation of the objectives shall be noted using the following details: in progress objectives, possible problems, suspension of implementation (for various reasons). It marks the anticipated and the actually achieved by month. As a result, the map data makes it easier to control the level of achievement of the objectives, to take into account the inconsistencies and difficulties encountered in a timely manner, to identify the necessary adjustments and to facilitate the PDCA cycle.

\subsection{Catchball and Ringi - in support of Hoshin Kanri}

The ball-catching principle referred above is a fundamental process under Hoshin Kanri. It gained popularity 
with the term "catchball". It sets out the idea of "catching" ideas, boiling down to the following: the executives of the higher level in the company formulate the strategic goals, then provide them for discussion to the middle-level leaders, they - the low-level leaders who bring them to the attention of everyone else, in order to be considered by all parties and to make proposals for changes. In this way, all staff makes their own personal contribution to improving the objectives according to the specifics (of the organization, the situation, the resources, the capabilities of the staff, etc.). The proposals are "returned" in stages to the senior managers until they reach the senior managers, who should formulate them definitively. The finalized objectives are in practice in a version that is approved by all the staff. Thus, they are socialized and can be regularly reviewed and updated if necessary (if the preliminary forecasts of the conditions change). Catchball means involving everyone in all processes. Achieving this requires continuous communication, providing feedback and engagement at all levels of the company (Tennant and Roberts, 2001, p.291). Improvement of management relationships is necessary to ensure continuity of processes. At the heart of Hoshin Kanri lies the formulation of strategies and policies for their implementation by making consensual decisions in order to make it possible to transform the objectives identified into day-to-day work actions. The Catchball process helps here. An important feature to be addressed is the fact that teamwork and consensual decision-making are often accompanied by the manifestation of the phenomenon of "group thinking". In practice, it leads to a decrease in the effectiveness of the decisions taken, as the group does not allow different thinking, putting pressure on its members in one way or another. Therefore, from the point of view of Catchball and Hoshin Kanri, the Ringi system is used to form consensus throughout the organization in Japanese companies. The term also consists of two components: "rin" and "gi". "Rin" means submitting ideas and suggestions to the direct manager and obtaining its approval, while "gi" is limited to discussion and resolution. As a result, Ringi is a bottom-up decision-making method in which people in the organization can safely express their possible disagreement or dissatisfaction by looking for ways to obtain unanimous approval of the final decision (Tennant and Roberts, 2001, p.292-293). Thus, the Ringi system is very closely related to the Catchball method, which allows improvement of operational decision-making. Catchball enables to build such a management style, securing the generation and sharing of original ideas that combine with the advantages of group analysis and agreement and can become part of the corporate strategy in the current and subsequent time period.

Practice shows that the end result of the Catchball process is tied to the development of tables on the basis of which planning takes place in the organization (Boisvert, 2012 p. 4). The high level of interaction makes plans and policies perceived by all staff. Carrying out reviews on the extent to which the planned objectives and indicators have been achieved allows for their continuous improvement.

\section{ACKNOWLEDGEMENT}

Hoshin Kanri or an expansion policy requires detailed objectives at all company levels, resulting in the necessary coordination for their implementation, as well as speeding up the process of responding to a change in the environment. Hoshin Kanri requires the participation of all managers in the annual activity planning to ensure universal staff engagement and a high degree of accuracy in setting goals and achieving them. Although the objectives are part of the long-term plan, they should be reviewed and revised in a timely manner. The main focus is on the ongoing processes and relevant feedback to assess the results obtained. Cooperation between all levels of governance in organizations enables the formulation of an up-to-date vision (at strategic level), definition of how to achieve the objectives (at the middle management level) as well as the actual implementation of what is set out in the plans (at executive team level). Communication between all levels is required to be of a two-way nature in order to provide feedback on the results achieved and their assessment by senior managers. Shared goal development and choice of actions are a prerequisite for a successful, strategical business.

\section{REFERENCE LIST}

Ahmed, H. (2016). A Proposed Systematic Framework forApplying Hoshin Kanri Strategic Planning Methodology in Educational Institutions. European Scientific Journal. Vol.12, No.16, pp. 158-194. doi: 10.19044/esj.2016.v12n16p158 URL:http://dx.doi.org/10.19044/esj.2016.v12n16p158

Alic, A., Ideskog, J. (2016). Hoshin Kanri - the Japanese way of piloting. An exploratory study of a Japanese strategic management system. [Online] Jönköping International Business School

Boisvert, L. (2012) Strategic Planning Using Hoshin Kanri. Founder Business Centered Learning ${ }^{T M}$ 
(bclearning.com)

Butterworth, R. (2001). Hoshiin Kanri: An exploratory study at Nissan Yamato engineering Itd. Durham theses, Durham University. Available at Durham E-Theses [Online] http://etheses.dur.ac.uk/4234/

Cwiklicki, M. (2010). TQM Methods Applied in the Hoshin Kanri Management System. 6th International Scientific Conference BUSINESS AND MANAGEMENT. Selected papers. Vilnius Gediminas Technical University, pp. 815-821. doi:10.3846/bm.2010.108

Ćwiklicki, M., Obora, H. (2011). Hoshin Kanri: Policy Management in Japanese Subsidiaries Based in Poland. Business, Management and Education. Vol. 9(2), pp. 216-235. http://dx.doi.org/10.3846/bme.2011.15

Häggström, A. (2004). Policy Controlled Environmental Management Work Problem Inventory Report. Chalmers University of Technology Göteborg, Sweden

Hutchins D. (2015). Hoshin Kanri: The Strategic Approach to Continuous Improvement.

Nicholas, J. (2014). Hoshin kanri and critical success factors in quality management and lean production. Total Quality Management. http://dx.doi.org/10.1080/14783363.2014.976938

Learning Enrichment Activity. Hoshin Kanri Planning. [Online] Available from: https://oakland.edu/Assets/upload/docs/Pawley/Lean-Enrichment-Activities/LEA---Hoshin-Kanri.pdf [Accessed 05/08/2020]

Paraschivescu, A. (2018). Hoshin Kanri and Total Quality Management. Economy Transdisciplinarity Cognition. Vol. 21, Issue 1/2018 pp. 91-98 // www.ugb.ro/etc

Souad, D., Messaouda, C. and Maazouzi, K. (2017). Planning using Hoshin Kanri. International Journal of Academic Research in Economics and Management Sciences. Vol. 6, (No. 4) http://dx.doi.org/10.6007/JJAREMS/v6-i4/3175

Tennant, C., Roberts, P. (2001). Hoshin Kanri: Implementing the Catchball Process. Long Range Planning, Vol. 34, pp. 287-308 (www.Irpjournal.com)

The definitive guide to hoshin kanri planning. [online] available from: https://www.smartsheet.com/hoshinkanri-planning [accessed 06/08/2020]

Winiarski, P. (2006). An Introduction to Hoshin Kanri, a.k.a. Strategic Goal Deployment ${ }^{\mathrm{TM}}-$ How to Use this Process to Deploy Your Strategic Goals. // www.WinEnterprisesLLC.com

Witcher B.J. (2014). Hoshin Kanri, Perspectives on Performance, 11(1), pp. 16-24.

Witcher B.J. (2003). Policy management of strategy (hoshin kanri). Strategic Change 12: pp. 83-94 (www.interscience.wiley.com). DOI: 10.1002/jsc.617

Zairi, M., Erskine, A. Excellence is Born out of Effective Strategic Deployment: The Impact of Hoshin Planning. International Journal of Applied Strategic Management. Volume 2, (Issue 2) Special Edition 